\title{
The effect of dietary yellow lupine (L. luteus cv. Baryt) on growth performance, carcass characteristics, meat quality and selected serum parameters of turkeys
}

\author{
M. Krawczyk, D. Mikulski', M. Przywitowski and J. Jankowski \\ University of Warmia and Mazury in Olsztyn, Department of Poultry Science, Oczapowskiego 5, 10-718 Olsztyn, Poland
}

KEY WORDS: yellow lupine, growth performance, carcass traits, meat quality, turkey

Received: 20 November 2014

Revised: 9 January 2015

Accepted: 16 March 2015
${ }^{1}$ Corresponding author:

e-mail: dariusz.mikulski@uwm.edu.pl

\begin{abstract}
This study evaluated the effects of dietary replacement of soyabean meal (SBM) with yellow lupine seed meal (YLM) in turkeys. A total of 1120 one-day-old Hybrid Converter female turkeys were fed diets containing $0 \%, 8 \%, 16 \%$ and $24 \%$ of YLM $\left(\mathrm{LM}_{0}, \mathrm{LM}_{8}, \mathrm{LM}_{16}, \mathrm{LM}_{24}\right.$, respectively) in a 16-week experiment. In the first phase of feeding (weeks $0-4$ ), an increase in the YLM content of diets caused a linear decrease in feed intake $(\mathrm{FI})$ and body weight gain (BWG) and the noted differences were significant $(P<0.001)$ in group LM ${ }_{24}$. In 16-week-old turkeys, dietary inclusion of lupine at up to $24 \%$ had no adverse effects on FI, BWG or feed conversion. Experimental diets had no influence on the analysed serum parameters or mortality of turkeys or on the incidence of footpad dermatitis. No significant changes in carcass and muscle yields were observed. Group $\mathrm{LM}_{24}$ turkeys were characterized by significantly $(P=0.033$ vs $L_{0}$ ) higher relative gizzard tissue weight. The abdominal fat content tended to increase $\left(P=0.055\right.$ vs $\left.L_{0}\right)$ in birds fed lupine-based diets. A linear increase $(P<0.001)$ in the concentrations of polyunsaturated fatty acids was noted in meat from turkeys fed lupine-based diets; this did not change the $n-6 / n-3$ PUFA ratio, but improved the values of the atherogenic and thrombogenic indices. Diets containing YLM had no influence on the chemical composition, physicochemical properties or sensory attributes of turkey meat. In conclusion, starter diets containing 24\% YLM could have an adverse influence on bird performance. Yellow lupine seeds can be added to diets for older turkeys at up to $24 \%$ as an effective substitute for SBM without affecting the key variables of performance and without negative effects on meat quality.
\end{abstract}

\section{Introduction}

Due to increased demand for high-protein feed components and high prices of soyabean meal (SBM) in the European Union, recent years have witnessed a growing interest in alternative vegetable protein sources in poultry diets (Nalle et al., 2011; Smulikowska et al., 2014; Zduńczyk et al., 2014). Lupin (Lupinus spp.) has a high protein content and could be a viable alternative to soyabeans that cannot be used in organic turkey diets. Seeds of modern sweet lupine varieties are characterized by low alkaloid concentrations (Jezierny et al., 2011) and relatively high amino acid digestibility in chickens and turkeys (Kozlowski et al., 2011; Nalle et al., 2012). Today, the major factor limiting the use of lupine seeds in poultry diets is their high content of non-starch polysaccharides (NSPs; up to $400 \mathrm{~g} \cdot \mathrm{kg}^{-1}$ ) 
and $\alpha$-galactosides known to exert antinutritional effects. Elevated levels of the above carbohydrate fractions in chicken and turkey diets may stimulate the proliferation and activity of gut microbiota (Zduńczyk et al., 2013), increase the viscosity of intestinal digesta and impair gut function, including food passage rate and nutrient utilization (Kocher et al., 2000).

The results of earlier studies indicate that the content of yellow lupine seeds in broiler chicken diets should be limited to 20\%-25\% (Orda et al., 2006 ) or even $10 \%-12 \%$ (Farrell et al., 1999). In a recent review of the latest research findings, Smulikowska et al. (2014) reported that the inclusion of sweet lupine at $15 \%$ of the diet can be accepted in older broilers, provided that the diet is supplemented with adequate amounts of amino acids and fat.

Very few studies have investigated the effects of lupine meals in turkey nutrition and the optimum inclusion levels of lupine seeds in diets for growing turkeys have not been determined to date. Recent research shows that $18 \%$ yellow lupine seeds can partially replace soyabean meal in grower/finisher diets for turkeys from 13 weeks of age (Zduńczyk et al., 2014). Diets supplemented with 18\% lupine seeds are relatively well tolerated by turkeys, they do not impair gastrointestinal function and have no adverse effects on growth performance, slaughter value, or meat quality, including sensory properties. However, there is a lack of published data on the efficacy of feeding lupine seeds to turkeys during the entire rearing period.

The objective of this study was to determine the effect of yellow lupine seed meal, administered from the first phase of feeding, on the growth performance of turkeys, carcass traits and on the chemical composition, physicochemical properties and sensory attributes of turkey meat.

\section{Material and methods}

The animal protocol used in this study was approved by the Local Animal Care and Use Committee (Olsztyn, Poland) and the study was carried out in accordance with EU Directive 2010/63/EU on the protection of animals used for scientific purposes (OJEU, 2010).

\section{Birds, management and diets}

A total of 1120 one-day-old Hybrid Converter female turkeys were randomly assigned to 4 dietary treatments, each consisting of 7 pens of 40 birds per pen. The birds were kept in pens on litter (wood shavings) in a building with a strictly controlled environment and they were reared to 16 weeks of age. Brooder and room temperature on the day of placement was set at $35^{\circ} \mathrm{C}$ and $28^{\circ} \mathrm{C}$, respectively, and was gradually decreased as needed. The following lighting programme was adopted: $24 \mathrm{~h}$ light with an intensity of $100 \mathrm{~lx}$ during the first $72 \mathrm{~h}$, followed by $18 \mathrm{~h}$ light per day until day 14 and $16 \mathrm{~h}$ light per day until the end of the growing period. Light intensity was reduced to $5 \mathrm{~lx}$ between days 3 and 7 and then gradually increased to $151 \mathrm{x}$ as of week 5 . The birds had free access to feed and water.

A wheat-soyabean meal-based control diet (group $\mathrm{L}_{0}$ ) and three diets containing $8 \%, 16 \%$ or $24 \%$ yellow lupine seed meal (YLM) (groups $\mathrm{LM}_{8}, \mathrm{LM}_{16}$ and $\mathrm{LM}_{24}$, respectively) were formulated to meet the nutrient requirements of turkeys as recommended by Hybrid Turkeys (2013). The nutrient content of diets was calculated based on the analysed chemical composition of SBM and YLM and according to the Recommended Allowances and Nutritive Value of Feedstuffs (in Polish; Smulikowska and Rutkowski, 2005). Certified yellow lupine seeds, cv. Baryt (Plant Breeding Station in Tulce, Wiatrowo, Poland) were used in this experiment. The apparent metabolizable energy (AME) content of lupine seeds was assumed at $9.0 \mathrm{MJ} \cdot \mathrm{kg}^{-1}$. A four-phase feeding programme, including starter (1-28 d of life), grower I (29-56 d), grower II (57-84 d) and finisher (85-112 d), was used during the study. Starter diets were offered as mash, while grower and finisher diets (29-112 d) were prepared as $3 \mathrm{~mm}$ pellets at $70^{\circ} \mathrm{C}$ by the Agrocentrum feed mill in Kaleczyn (Poland). The composition and calculated analysis of experimental diets are given in Table 1 and the chemical composition of SBM and YLM is given in Table 2.

\section{Sample collection and chemical analysis}

Samples of SBM and YLM were analysed for dry matter (DM; method 934.01), crude protein $(\mathrm{N} \times 6.25$; method 976.05), ether extract (method 920.39), crude fibre (method 978.10) and ash (method 942.05) as described by AOAC (2005), amino acids (Zduńczyk et al., 2014), alkaloids (Muzquiz et al., 1996), non-starch polysaccharides - by gas - liquid chromatography (component neutral sugars) and by a colorimetric method (uronic acids) as described by Slominski and Campbell (1990) and raffinose family oligosaccharides (RFOs; raffinose, stachyose and verbascose) as described by Slominski et al. (1993).

Body weight (BW) and feed conversion ratio (FCR) were recorded on days 28, 56, 84 and 112. At 16 weeks of age, 5 samples of fresh excreta per replicate were randomly collected, pooled 
Table 1. Ingredient composition and nutrient content of experimental diets, $\mathrm{g} \cdot \mathrm{kg}^{-1}$, as-fed basis

\begin{tabular}{|c|c|c|c|c|c|c|c|c|c|c|c|c|c|c|c|c|}
\hline \multirow{2}{*}{ Specification } & \multicolumn{4}{|c|}{ Weeks 0-4 } & \multicolumn{4}{|c|}{ Weeks 5-8 } & \multicolumn{4}{|c|}{ Weeks 9-12 } & \multicolumn{4}{|c|}{ Weeks 13-16 } \\
\hline & $\mathrm{LM}_{0}$ & $\mathrm{LM}_{8}$ & $\mathrm{LM}_{16}$ & $\mathrm{LM}_{24}$ & $\mathrm{LM}_{0}$ & $\mathrm{LM}_{8}$ & $\mathrm{LM}_{16}$ & $\mathrm{LM}_{24}$ & $\mathrm{LM}_{0}$ & $\mathrm{LM}_{8}$ & $\mathrm{LM}_{16}$ & $\mathrm{LM}_{24}$ & $\mathrm{LM}_{0}$ & $\mathrm{LM}_{8}$ & $\mathrm{LM}_{16}$ & $\mathrm{LM}_{24}$ \\
\hline \multicolumn{17}{|l|}{ Ingredient } \\
\hline & 3.0 & 306.6 & 280.1 & 253.7 & 314.5 & 288.0 & 261.6 & 235.1 & 583.8 & 560.6 & 537.3 & 514.0 & 699.8 & 676.4 & 653.2 & 630.0 \\
\hline m & 150.0 & 150.0 & 150.0 & 150.0 & 150.0 & 150.0 & 150.0 & 150.0 & - & - & - & - & - & - & - & - \\
\hline & - & 80.0 & 160.0 & 240.0 & - & 80.0 & 160.0 & 240.0 & - & 80.0 & 160.0 & 240.0 & - & 80.0 & 160.0 & 240.0 \\
\hline $\begin{array}{r}\text { potato } \\
(75.2\end{array}$ & 40.0 & 0.0 & 0 & 40.0 & - & - & - & . & - & - & - & 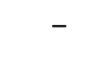 & - & - & _ & - \\
\hline $\begin{array}{r}\text { soyabe } \\
\quad 46 \%\end{array}$ & 410.2 & 349.4 & 288.6 & 27.9 & 447.6 & 386.8 & 326.0 & 265.3 & 327.4 & 265.8 & 204.1 & 143.5 & 221.2 & 159.6 & 98.0 & 36. \\
\hline soya & 14.3 & 21.1 & 0 & 34.8 & 42.8 & 49.7 & 56 & 63 & 47.5 & 52.0 & 56.5 & 61 & 46.3 & 50.8 & 55.3 & 59. \\
\hline & 17.2 & 7.1 & & 9 & 15.7 & 15.6 & .5 & & 14.2 & 14.2 & 14.1 & 14.0 & 10.7 & 10.7 & 10.6 & 10.5 \\
\hline mo & 19.1 & 19.2 & 19.3 & 19.4 & 16.2 & 16.3 & 16.4 & 16.5 & 12.6 & 12.7 & 12.8 & 12.9 & 7.7 & 7.7 & 7.8 & 8.0 \\
\hline $\mathrm{N}$ & 2.5 & 2.5 & 2.5 & 2.5 & 2.0 & 2.0 & 2.0 & 2.0 & 2.1 & 2.1 & 2. & 2. & 2.2 & 2. & 2.2 & 2.2 \\
\hline cholin & - & - & - & - & - & - & - & - & 0.7 & 0.7 & 0.7 & 0.7 & 0.7 & 0.7 & 0.7 & 0.7 \\
\hline $\mathrm{NaHCO}_{3}$ & 1.0 & 1.0 & 1.0 & 1.0 & 1.0 & 1.0 & 1.0 & 1.0 & 1.0 & 1.0 & 1.0 & 1.0 & 1.0 & 1.0 & 1.0 & 1. \\
\hline & 3.3 & 3.3 & 3.3 & 3.2 & 3.4 & 3.4 & 3.3 & 20 & 3.0 & 3.0 & 3.0 & 3.0 & 2.9 & 2.9 & 2.8 & 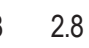 \\
\hline L-Lys H & 3.6 & 3.8 & 4.0 & 4.3 & 3.6 & 3.9 & 4.1 & 4.3 & 4.2 & 4.4 & 4.6 & 4.9 & 4.2 & 4.5 & 4.7 & 4. \\
\hline L-Thr (98,5\%) & 0.7 & 0.9 & 1.0 & 1.2 & 0.7 & 0.9 & 1.1 & 1.2 & 0.9 & 1.0 & 1.2 & 1.4 & 0.8 & 1.0 & 1.2 & ? \\
\hline vit.-min. mixture ${ }^{1}$ & 5.0 & 5.0 & 5.0 & 5.0 & 2.5 & 2.5 & 2.5 & 2.5 & 2.5 & 2.5 & 2.5 & 2.5 & 2.5 & 2.5 & 2.5 & 2.5 \\
\hline
\end{tabular}

Calculated $^{2}$

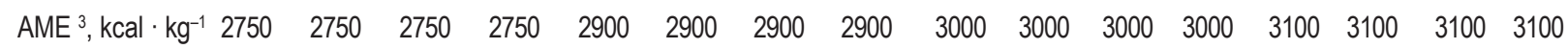
$\begin{array}{lllllllllllllllll}\text { crude protein } & 275.1 & 274.5 & 273.9 & 274.0 & 261.2 & 259.0 & 262.3 & 258.6 & 222.5 & 221.4 & 220.5 & 224.1 & 189.2 & 192.2 & 187.3 & 187.9\end{array}$ (analysed)

\begin{tabular}{|c|c|c|c|c|c|c|c|c|c|c|c|c|c|c|c|c|}
\hline $\mathrm{NSP}^{4}$ & 101.2 & 113.3 & 125.4 & 137.5 & 104.1 & 116.1 & 128.2 & 140.3 & 103.0 & 115.4 & 127.7 & 140.1 & 101.6 & 113.9 & 126.2 & 138.5 \\
\hline $\mathrm{RFO}^{5}$ & 28.1 & 31.5 & 35.0 & 38.4 & 30.0 & 33.4 & 36.9 & 40.3 & 20.7 & 24.1 & 27.5 & 31.0 & 15.7 & 19.1 & 22.5 & 25.9 \\
\hline arginine & 17.0 & 18.3 & 19.6 & 20.9 & 16.7 & 17.9 & 19.2 & 20.5 & 13.7 & 15.0 & 16.3 & 17.5 & 11.0 & 12.3 & 13.6 & 14.8 \\
\hline lysine & 17.5 & 17.5 & 17.5 & 17.5 & 16.3 & 16.3 & 16.3 & 16.3 & 14.0 & 14.0 & 14.0 & 14.0 & 11.6 & 11.6 & 11.6 & 11.6 \\
\hline Met and Cys & 11.7 & 11.7 & 11.7 & 11.7 & 11.2 & 11.2 & 11.2 & 11.2 & 10.0 & 10.0 & 10.0 & 10.0 & 9.0 & 9.0 & 9.0 & 9.0 \\
\hline threonine & 11.0 & 11.0 & 11.0 & 11.0 & 10.0 & 10.0 & 10.0 & 10.0 & 8.5 & 8.5 & 8.5 & 8.5 & 7.0 & 7.0 & 7.0 & 7.0 \\
\hline $\mathrm{Ca}$ & 12.5 & 12.5 & 12.5 & 12.5 & 11.0 & 11.0 & 11.0 & 11.0 & 9.5 & 9.5 & 9.5 & 9.5 & 7.0 & 7.0 & 7.0 & 7.0 \\
\hline vailable $P$ & 5.8 & 5.8 & 5.8 & 5.8 & 5.2 & 5.2 & 5.2 & 5.2 & 4.6 & 4.6 & 4.6 & 4.6 & 3.5 & 3.5 & 3.5 & 3.5 \\
\hline
\end{tabular}

$L_{0}, L_{8}, L_{16}, L_{24}-0,8,16$ and $24 \%$ yellow lupine seed meal in the diet as a partial replacement for soyabean meal and wheat; ${ }^{1}$ provided per $\mathrm{kg}$ feed (feeding periods: weeks $0-4,5-8,9-12$ and 13-16): $\mathrm{mg}$ : retinol 3.78, 3.38, 2.88 and 2.52, cholecalciferol 0.13, $0.12,0.10$ and 0.09 , a-tocopheryl acetate $100,90,80$ and 70 , vit. $\mathrm{K}_{3} 5.8,5.6,4.8$ and 4.2 , thiamine $5.4,4.7,4.0$ and 3.5 , riboflavin $8.4,7.5,6.4$ and 5.6, pyridoxine 6.4, 5.6, 4.8 and 4.2, cobalamin $0.032,0.028,0.024$ and 0.021 , biotin $0.32,0.28,0.24$ and 0.21 , pantothenic acid $28,24,20$ and 18 , nicotinic acid 84, 75, 64 and 56, folic acid 3.2, 2.8, 2.4 and 2.1, Fe 64, 60, 56, 48 and 42, Mn 120, 112, 96 and 84, Zn 110, 103, 88 and 77, Cu 23, 19, 16 and 14, I 3.2, 2.8, 2.4 and 2.1, Se 0.30, 0.28, 0.24 and 0.21 , choline chloride 400, 376, 320 and 280, respectively; ${ }^{2}$ calculated from the analysed chemical composition of soyabean meal and yellow lupine seed meal, and according to the Recommended Allowances and Nutritive Value of Feedstuffs (Smulikowska and Rutkowski, 2005); ${ }^{3}$ AME - apparent metabolizable energy, ${ }^{4} \mathrm{NSP}$ - non-starch polysaccharides, ${ }^{5} \mathrm{RFO}$ - raffinose family oligosaccharides

(7 replicates per dietary treatment) and assayed for DM content. At 112 days of age, all birds were weighed, and footpad dermatitis (FPD) scores were determined according to the method described by Hocking et al. (2008). The proposed classification system included 5 categories ranging from 0 to 4 . Mortality rates, including their causes, were monitored on a daily basis.

At the termination of the experiment, 7 birds were randomly selected from each treatment (one turkey per pen) and lithium-heparinized blood samples were obtained by wing vein puncture with a $25 \mathrm{G}$ needle. Plasma was separated by centrifugation $\left(1500 \mathrm{rpm}\right.$ for $10 \mathrm{~min}$ at $\left.4^{\circ} \mathrm{C}\right)$ and stored for
$24 \mathrm{~h}$ at $-20^{\circ} \mathrm{C}$ until analysed for serum chemical components: total protein, triglycerides, total cholesterol, glucose, ammonia, calcium, phosphorus, aspartate aminotransferase, alanine aminotransferase and alkaline phosphatase. The above parameters were analysed in a VetTest 8008 analyzer (Idexx Laboratories, Inc., Westbrook, Maine 04092, USA). The same 7 birds from each treatment (one subsample per replicate pen) were killed at the Department's slaughterhouse $8 \mathrm{~h}$ after feed withdrawal. The birds (not transported) were electrically stunned (400 mA, $350 \mathrm{~Hz}$ ), hung on a shackle line and exsanguinated by a unilateral neck cut severing the right carotid artery and jugular vein. After a 3-min bleeding period, 
Table 2. Chemical composition of soyabean meal and yellow lupine seed meal

\begin{tabular}{|c|c|c|}
\hline Component & $\begin{array}{l}\text { Soyabean } \\
\text { meal }\end{array}$ & $\begin{array}{l}\text { Lupine } \\
\text { seed meal } \\
\text { cv. Baryt }\end{array}$ \\
\hline Dry matter, \% & 90.9 & 93.64 \\
\hline Crude protein, \% DM & 50.60 & 41.45 \\
\hline Neutral detergent fibre, \% DM & 9.61 & 25.72 \\
\hline Crude ash, \% DM & 6.47 & 4.60 \\
\hline Crude fat, \% DM & 2.85 & 5.47 \\
\hline Crude fibre, \% DM & 3.82 & 17.18 \\
\hline Non-starch polysaccharides, \% DM & 14.05 & 30.22 \\
\hline arabinose & 2.22 & 3.94 \\
\hline xylose & 1.01 & 3.49 \\
\hline mannose & 0.55 & 0.45 \\
\hline galactose & 4.27 & 5.82 \\
\hline glucose & 3.43 & 12.60 \\
\hline uronic acid & 2.35 & 3.99 \\
\hline Raffinose family oligosaccharides, $\%$ DM & 5.91 & 9.13 \\
\hline raffinose & 1.16 & 0.92 \\
\hline stachyose & 4.47 & 4.88 \\
\hline verbascose & 0.28 & 3.33 \\
\hline \multicolumn{3}{|l|}{ Amino acid composition, $\mathrm{g} \cdot 100 \mathrm{~g}^{-1} \mathrm{CP}$} \\
\hline arginine & 7.14 & 9.93 \\
\hline histidine & 2.60 & 2.69 \\
\hline isoleucine & 4.53 & 3.60 \\
\hline leucine & 7.57 & 6.90 \\
\hline lysine & 6.03 & 4.38 \\
\hline methionine & 1.32 & 0.51 \\
\hline cystine & 1.45 & 2.36 \\
\hline phenylalanine & 5.03 & 3.48 \\
\hline threonine & 3.91 & 3.07 \\
\hline Alkaloids, $\mathrm{mg} \cdot \mathrm{kg}^{-1}$ & not determined & d $310^{1}$ \\
\hline
\end{tabular}

${ }^{1}$ including, mg: lupinine 259.1 , sparteine 36.0 , epilupinine 9.5 , ammodendrine 5.5

the birds were scalded at $61{ }^{\circ} \mathrm{C}$ for $60 \mathrm{~s}$, defeathered in a rotary drum picker for $25 \mathrm{~s}$, and manually eviscerated (non-edible viscera: intestines, proventriculus, gall bladder, spleen, oesophagus and full crop). Head, neck, legs, edible viscera (heart, liver and gizzard), fat (perivisceral, perineal and abdominal) and the first joint to the wing tip were removed to obtain ready-to-cook carcasses. Following evisceration, whole carcasses were air pre-chilled at $12^{\circ} \mathrm{C}$ for 30 min, air chilled, stored at $4^{\circ} \mathrm{C}$, and hand-deboned on a cone $24 \mathrm{~h}$ post mortem. The yields of whole carcass, breast muscles (including the pectoralis major and pectoralis minor muscles) and leg muscles (including the thigh and drumstick without skin), liver weight, gizzard weight and abdominal fat content were determined relative to live BW.

At the time of deboning ( $24 \mathrm{~h}$ post mortem), the pectoralis major subsamples were used to determine $\mathrm{pH}$ value, meat colour, weight loss during cooking and shearing force values. The remaining portion of the breast meat was vacuum-packaged, frozen at $-20^{\circ} \mathrm{C}$, and stored for further analysis (chemical composition and fatty acid profile). Meat colour was determined by the optical reflection method in a CIELAB system (CIE, 1978) with L* (lightness, lower values indicate a darker colour), $\mathrm{a}^{*}$ (redness, higher positive values indicate a higher contribution of redness) and $b^{*}$ (yellowness, higher positive values indicate a higher contribution of yellowness) measured using a MiniScan XE Plus colourdifference meter (Hunter Associates Laboratory, Inc., Reston, VA, USA). The average of two readings taken from the cross-section of each right breast muscle free from colour defects, bruising and haemorrhages was recorded. Ultimate $\mathrm{pH}$ ( $24 \mathrm{~h}$ post mortem) was measured in duplicate at a depth of $2.5 \mathrm{~cm}$ below the surface of the left breast muscle, using a portable $\mathrm{pH} /{ }^{\circ} \mathrm{C}$ measuring instrument Testo 206-pH2 and a $\mathrm{pH} 2$ piercing probe head for semi-solid substances (Testo GmbH \& Co., Lenzkirch, Germany). To determine cooking loss, breast meat samples were weighed (initial weight, wti), cooked in a microwave oven (12 min at $480 \mathrm{~W}$ ) and weighed again (weight after cooking, wtc). Cooking loss was calculated as $[(w t i-w t c) / w t i] \times 100$. Following cooking, WarnerBratzler shear force (WBS) was determined using a universal Instron 5542 testing machine (Instron Ltd., High Wycombe, UK) equipped with a 500-N load cell. For this purpose, five cylinders, $1.27 \mathrm{~cm}$ in diameter and $2 \mathrm{~cm}$ in height, were cut out from meat samples and stored in aluminum foil at $4^{\circ} \mathrm{C}$ for $24 \mathrm{~h}$. The maximum shear force required to cut each of the cylinders across the fibres was recorded.

Approximately 5 days after slaughter, the content of dry matter, ash, protein and fat in breast meat samples was determined in triplicate using AOAC (2005) methods 934.01, 942.05, 976.05 and 920.39, respectively. Total cholesterol concentrations and the fatty acid (FA) profile were determined in fat separated via extraction from the meat with a chloroform and methanol mixture $(2: 1 \mathrm{v} / \mathrm{v}$; Folch et al., 1957). Cholesterol was separated from fat after saponification with $\mathrm{KOH}$ and extraction with ethyl ether, by the modified method of the International Dairy Federation (1992). The samples were subjected to chromatographic analysis in a PU-4600 (Pye Unicam, Cambridge, UK) chromatograph with a flame ionization detector (FID), under the following conditions: length of the glass column: $1 \mathrm{~m}$; internal diameter: $4 \mathrm{~mm}$; film thickness: $0.25 \mu \mathrm{m}$; temperature: detector, $300^{\circ} \mathrm{C}$, injector, $290^{\circ} \mathrm{C}$, column, $260^{\circ} \mathrm{C}$; carrier gas: argon; flow rate: $50 \mathrm{~cm}^{3} / \mathrm{min}$; internal standard: dotriacontane (Sigma, St. Louis, MO, USA). The cholesterol content was calculated and expressed as milligrams per gram of meat lipids. 
The extracted fat was esterified with a chloroform, methanol and sulphuric acid mixture, as described by Peisker (1964). The resulting fatty acid methyl esters (FAMEs) were analysed in a 7890A gas chromatograph (Agilent Technologies Inc., Palo Alto, CA, USA) with a FID and a Supelcowax 10 capillary column (column length: $30 \mathrm{~m}$; internal diameter: $0.32 \mathrm{~mm}$; film thickness: $0.25 \mu \mathrm{m}$; carrier gas: helium; temperature: detector, $250^{\circ} \mathrm{C}$, injector, $230^{\circ} \mathrm{C}$, column, $195^{\circ} \mathrm{C}$ ). The FA peaks were identified by comparing their relative retention times with those of individual FAME reference standards (Supelco) diluted in hexane $(1: 1,1: 2,1: 3,1: 4 \mathrm{v} / \mathrm{v})$. The atherogenic index (AI) and the thrombogenic (TI) index were calculated according to Ulbricht and Southgate (1991):

$$
\begin{aligned}
\mathrm{AI}= & \mathrm{C} 12: 0+4 \times \mathrm{C} 14: 0+\mathrm{C} 16: 0 / \text { MUFA }+ \text { PUFA } \\
\mathrm{TI}= & \mathrm{C} 14: 0+\mathrm{C} 16: 0+\mathrm{C} 18: 0 /(0.5 \times \mathrm{MUFA})+ \\
& +(0.5 \times \mathrm{n}-6 \text { PUFA })+(3 \times \mathrm{n}-3 \text { PUFA })+ \\
& +(\mathrm{n}-3 \text { PUFA } / \mathrm{n}-6 \text { PUFA })
\end{aligned}
$$

Samples of cooked breast meat were also subjected to sensory analysis performed by a six-member trained panel experienced in descriptive analysis of different food products and familiarized with the sensory quality of meat. All laboratory procedures used in this study have been described elsewhere (Zduńczyk et al., 2014).

\section{Statistical analysis}

For performance parameters, excreta DM content and FPD scores, a pen was considered as a replicate experimental unit for the statistical analysis. Other results were analysed with every turkey as a replicate. The model assumptions of normality and homogeneity of variance were examined by the Shapiro-Wilk and Levene tests, respectively. One-way ANOVA and the Newman-Keuls multiple comparison test were performed to determine differences between treatment means. In addition, linear and quadratic polynomial contrast were used to evaluate the effect of lupine inclusion level in experimental diets. All calculations were performed using the STATISTICA software system ver. 10 (Statsoft, Inc., 2011). Variability in the data was expressed as a pooled SE, and $P<0.05$ was considered statistically significant, whereas $P<0.10$ was considered a tendency.

\section{Results}

As shown in Table 2, YLM had a relatively high protein content and a moderate fat content in comparison with SBM, but it also had a relatively high alkaloid content relative to the appropriate standards for sweet lupines. The concentrations of structural carbohydrates, determined as crude fibre and NSPs, were higher compared with SBM. The arginine content was higher in YLM compared with SBM, whereas lysine and methionine levels were relatively low. The diet with $24 \%$ of YLM contained approximately 29,37 and $10 \mathrm{~g} \cdot \mathrm{kg}^{-1}$ more of crude fibre, NSPs and RFOs, respectively, compared with the control diet (Table 1).

Table 3 presents the growth performance parameters of turkeys during a 16 -week rearing period. In the first phase of feeding (weeks $0-4$ ), an increase in the YLM content of diets caused a linear decrease in feed intake (FI) and body weight gain $(\mathrm{BWG})$ and the noted differences were significant $(P<0.001)$ in group $\mathrm{LM}_{24}$. In subsequent feeding phases and during the entire 16-week rearing period, dietary inclusion of lupine at up to $24 \%$ had no adverse effects on FI, BWG or feed conversion. At 16 weeks of age, birds from control group and turkeys fed diets containing 24\% YLM were characterized by a similar BWG $(10.6 \mathrm{~kg}$ and $10.8 \mathrm{~kg})$ and feed conversion ( 2.49 and $2.55 \mathrm{~kg} \cdot \mathrm{kg}^{-1}$, respectively; $P=0.160$ ). The BWG of turkeys fed diets containing $8 \%$ and $16 \%$ YLM was even higher than in the control group $(P=0.009)$.

Lupine-based diets had no influence on excreta moisture content. Excreta DM content was comparable in turkeys fed diets containing YLM and in the control group. A linear decrease $(P=0.005)$ in FPD scores was noted with increasing dietary inclusion levels of YLM. The severity of FDP was significantly $(P=0.035)$ lower in group $\mathrm{LM}_{24}$ than in control group $\mathrm{LM}_{0}$. During the performance trial, mortality rates were negligible (0.4-1.4\%) and bird deaths were not related to any specific dietary treatment (Table 4).

The diet containing up to $24 \%$ YLM had no effect on any of the analysed serum biochemical parameters of turkeys, including liver function (Table 5). No significant changes in the carcass dressing percentage or carcass muscle yield were observed (Table 6). In comparison with diet $\mathrm{LM}_{0}$, turkeys receiving $\operatorname{diet} \mathrm{LM}_{24}$ were characterized by significantly higher relative gizzard tissue weight $(P=0.033)$. The abdominal fat content tended to increase $\left(P=0.055\right.$ vs $\left.\mathrm{LM}_{0}\right)$ in birds fed lupine-based diets.

The chemical composition of turkey meat, including cholesterol levels, as well as its physicochemical properties such as $\mathrm{pH}$, cooking loss and shear force values, were similar in all dietary treatments (Table 6). The colour of turkey meat in groups $\mathrm{LM}_{16}$ and $\mathrm{LM}_{24}$ was characterized by a higher contribution of yellowness compared with control group $\mathrm{LM}_{0}(P=0.034)$. Diets containing YLM did 
Table 3. The effect of different levels of yellow lupine seed meal on the growth performance of turkeys from 0 to 16 weeks of age ${ }^{1}$

\begin{tabular}{|c|c|c|c|c|c|c|c|c|}
\hline \multirow{2}{*}{ Indices } & \multicolumn{4}{|c|}{ Treatment $^{2}$} & \multirow{2}{*}{ SEM } & \multicolumn{3}{|l|}{$P$} \\
\hline & $\mathrm{LM}_{0}$ & $\mathrm{LM}_{8}$ & $\mathrm{LM}_{16}$ & $\mathrm{LM}_{24}$ & & group & linear & quadratic \\
\hline \multicolumn{9}{|c|}{ Daily feed intake, g/bird } \\
\hline weeks: $1-4$ & $51.3^{\mathrm{a}}$ & $50.6^{\mathrm{a}}$ & $48.1^{b}$ & $45.6^{c}$ & 0.492 & 0.001 & $<0.001$ & 0.059 \\
\hline $5-8$ & 186.1 & 188.5 & 187.7 & 182.2 & 1.383 & 0.381 & 0.332 & 0.164 \\
\hline $9-12$ & 334.1 & 338.8 & 337.0 & 322.9 & 2.494 & 0.086 & 0.105 & 0.054 \\
\hline $13-16$ & 429.5 & 454.6 & 442.3 & 442.8 & 3.438 & 0.087 & 0.350 & 0.067 \\
\hline $1-16$ & $241.8^{a}$ & $246.3^{a}$ & $243.3^{a}$ & $233.2^{b}$ & 1.624 & 0.015 & 0.030 & 0.015 \\
\hline \multicolumn{9}{|c|}{ Body weight gain, $\mathrm{kg} / \mathrm{bird}$} \\
\hline weeks: $1-4$ & $0.83^{\mathrm{a}}$ & $0.83^{\mathrm{a}}$ & $0.82^{\mathrm{a}}$ & $0.77^{b}$ & 0.006 & 0.001 & $<0.001$ & 0.025 \\
\hline $5-8$ & $2.51^{\mathrm{b}}$ & $2.68^{\mathrm{a}}$ & $2.70^{\mathrm{a}}$ & $2.63^{a}$ & 0.023 & 0.012 & 0.039 & 0.005 \\
\hline $9-12$ & 3.85 & 3.88 & 3.94 & 3.74 & 0.032 & 0.148 & 0.310 & 0.072 \\
\hline $13-16$ & $3.46^{b}$ & $3.65^{\mathrm{a}}$ & $3.54^{\mathrm{ab}}$ & $3.65^{\mathrm{a}}$ & 0.028 & 0.028 & 0.041 & 0.447 \\
\hline $1-16$ & $10.64^{b}$ & $11.04^{\mathrm{a}}$ & $10.99^{a}$ & $10.80^{\mathrm{ab}}$ & 0.049 & 0.009 & 0.280 & 0.001 \\
\hline \multicolumn{9}{|c|}{ Feed conversion ratio, $\mathrm{kg} \cdot \mathrm{kg}^{-1}$ of BWG } \\
\hline weeks: $1-4$ & $1.74^{\mathrm{a}}$ & $1.73^{\mathrm{ac}}$ & $1.66^{b}$ & $1.68^{\mathrm{bc}}$ & 0.011 & 0.008 & 0.003 & 0.340 \\
\hline $5-8$ & $2.08^{a}$ & $1.95^{b}$ & $1.94^{b}$ & $1.91^{b}$ & 0.016 & $<0.001$ & $<0.001$ & 0.017 \\
\hline $9-12$ & 2.39 & 2.42 & 2.42 & 2.41 & 0.013 & 0.910 & 0.662 & 0.588 \\
\hline $13-16$ & 3.34 & 3.37 & 3.37 & 3.28 & 0.024 & 0.511 & 0.379 & 0.250 \\
\hline $1-16$ & 2.55 & 2.53 & 2.52 & 2.49 & 0.011 & 0.160 & 0.027 & 0.938 \\
\hline
\end{tabular}

${ }^{1}$ data represent mean values of 7 pens per treatment; SEM - standard error of the mean (SD divided by the square root of replication number, $\mathrm{n}=28) ;{ }^{2}$ see Table $1 ;$ a,b means with different superscripts within a row are significantly different at $P<0.05$

Table 4. Excreta dry matter (DM) content, footpad dermatitis (FPD) score and mortality of turkeys fed diets containing yellow lupine seed meal ${ }^{1}$

\begin{tabular}{|c|c|c|c|c|c|c|c|c|}
\hline \multirow{2}{*}{ Indices } & \multicolumn{4}{|c|}{ Treatment $^{2}$} & \multirow{2}{*}{ SEM } & \multicolumn{3}{|l|}{$P$} \\
\hline & $\mathrm{LM}_{0}$ & $\mathrm{LM}_{8}$ & $\mathrm{LM}_{16}$ & $\mathrm{LM}_{24}$ & & group & linear & quadratic \\
\hline DM content, \% & 23.5 & 24.0 & 24.4 & 25.0 & 0.426 & 0.680 & 0.234 & 0.966 \\
\hline $\mathrm{FPD}^{3}$ & $2.35^{a}$ & $2.23^{\mathrm{ab}}$ & $2.01^{\mathrm{ab}}$ & $1.69^{b}$ & 0.089 & 0.035 & 0.005 & 0.517 \\
\hline \multicolumn{9}{|l|}{ Mortality, \% } \\
\hline weeks $1-16$ & 0.83 & 0.36 & 1.43 & 1.43 & & & & \\
\hline
\end{tabular}

${ }^{1}$ data represent mean values of 7 pens per treatment; SEM - standard error of the mean (SD divided by the square root of replication number, $\mathrm{n}=28) ;{ }^{2}$ see Table $1 ;{ }^{3} \mathrm{FPD}$ - footpad dermatitis, scale from 0 to $4 ;{ }^{\mathrm{a}, \mathrm{b}}$ means with different superscripts within a row are significantly different at $P<0.05$

Table 5. Blood biochemical parameters of turkeys fed diets with increasing levels of yellow lupine seed meal ${ }^{1}$

\begin{tabular}{|c|c|c|c|c|c|c|c|c|}
\hline \multirow{2}{*}{ Indices } & \multicolumn{4}{|c|}{ Treatment $^{2}$} & \multirow{2}{*}{$\begin{array}{l}\text { Pooled } \\
\text { SEM }\end{array}$} & \multicolumn{3}{|l|}{$P$} \\
\hline & $\overline{\mathrm{LM}_{0}}$ & $\mathrm{LM}_{8}$ & $\mathrm{LM}_{16}$ & $\mathrm{LM}_{24}$ & & group & linear & quadratic \\
\hline$\overline{A L T}, U \cdot I^{-1}$ & 24.7 & 22.0 & 16.9 & 22.8 & 1.369 & 0.218 & 0.380 & 0.115 \\
\hline$A S T, U \cdot I^{-1}$ & 448 & 435 & 424 & 458 & 14.0 & 0.849 & 0.877 & 0.426 \\
\hline$A L K P, U \cdot I^{-1}$ & 286 & 266 & 248 & 313 & 9.39 & 0.073 & 0.430 & 0.021 \\
\hline Total protein, $\mathrm{g} \cdot \mathrm{dl}^{-1}$ & 2.87 & 2.90 & 2.64 & 2.87 & 0.095 & 0.777 & 0.774 & 0.618 \\
\hline Triglyceride, $\mathrm{mg} \cdot \mathrm{dl}^{-1}$ & 55.7 & 64.3 & 66.9 & 81.4 & 4.09 & 0.162 & 0.032 & 0.705 \\
\hline Cholesterol, $\mathrm{mg} \cdot \mathrm{dl}^{-1}$ & 83.6 & 76.0 & 77.7 & 89.3 & 3.128 & 0.444 & 0.508 & 0.141 \\
\hline Glucose, $\mathrm{mg} \cdot \mathrm{dl}^{-1}$ & 225 & 228 & 212 & 259 & 6.54 & 0.064 & 0.114 & 0.082 \\
\hline Ammonia, $\mu \mathrm{mol} \cdot \mathrm{l}^{-1}$ & 298 & 315 & 243 & 280 & 12.89 & 0.231 & 0.268 & 0.687 \\
\hline $\mathrm{Ca}, \mathrm{mg} \cdot \mathrm{dl}^{-1}$ & 8.29 & 8.74 & 7.96 & 9.09 & 0.212 & 0.257 & 0.393 & 0.426 \\
\hline $\mathrm{P}, \mathrm{mg} \cdot \mathrm{dl}^{-1}$ & 5.66 & 6.34 & 5.67 & 6.13 & 0.165 & 0.378 & 0.618 & 0.731 \\
\hline
\end{tabular}

${ }^{1}$ data represent mean values of 7 turkeys per treatment; SEM - standard error of the mean (SD divided by the square root of replication number, $\mathrm{n}=28) ;{ }^{2}$ see Table 1; ALT - alanine aminotransferase; AST - aspartate aminotransferase; ALKP - alkaline phosphatase 
Table 6. The effect of different levels of yellow lupine seed meal (LM, \%) on carcass characteristics, chemical composition and physicochemical properties of breast meat in turkeys at 112 days of age ${ }^{1}$

\begin{tabular}{|c|c|c|c|c|c|c|c|c|}
\hline \multirow{2}{*}{ Item } & \multicolumn{4}{|c|}{ Treatment ${ }^{2}$} & \multirow{2}{*}{$\begin{array}{l}\text { Pooled } \\
\text { SEM }\end{array}$} & \multicolumn{3}{|l|}{$P$} \\
\hline & $\mathrm{LM}_{0}$ & $\mathrm{LM}_{8}$ & $\mathrm{LM}_{16}$ & $\mathrm{LM}_{24}$ & & group & linear & quadratic \\
\hline Dressing percentage & 81.0 & 81.3 & 82.0 & 80.4 & 0.268 & 0.177 & 0.613 & 0.070 \\
\hline \multicolumn{9}{|l|}{$\mathrm{g} \cdot 100 \mathrm{~g}^{-1}$ body weight (BW) } \\
\hline thigh muscles & 10.7 & 10.4 & 10.4 & 10.1 & 0.099 & 0.203 & 0.053 & 0.803 \\
\hline drumstick muscles & 7.79 & 7.95 & 7.62 & 7.65 & 0.104 & 0.680 & 0.443 & 0.761 \\
\hline abdominal fat & 1.09 & 1.34 & 1.67 & 1.44 & 0.079 & 0.055 & 0.037 & 0.103 \\
\hline liver relative weight & 1.09 & 1.10 & 1.09 & 1.04 & 0.020 & 0.740 & 0.402 & 0,481 \\
\hline gizzard relative weight & $0.79^{b}$ & $0.78^{b}$ & $0.77^{b}$ & $0.94^{a}$ & 0.024 & 0.033 & 0.026 & 0.059 \\
\hline \multicolumn{9}{|l|}{ Breast meat, skinless } \\
\hline relative weight, $\mathrm{g} \cdot 100 \mathrm{~g}^{-1} \mathrm{BW}$ & 23.11 & 24.06 & 23.59 & 22.68 & 0.332 & 0.513 & 0.566 & 0.179 \\
\hline $\mathrm{DM}, \mathrm{g} \cdot 100 \mathrm{~g}^{-1}$ & 26.75 & 26.48 & 26.73 & 26.66 & 0.071 & 0.544 & 0.993 & 0.493 \\
\hline protein, $\mathrm{g} \cdot 100 \mathrm{~g}^{-1}$ & 25.85 & 25.40 & 25.68 & 25.43 & 0.095 & 0.286 & 0.250 & 0.595 \\
\hline fat, $\mathrm{g} \cdot 100 \mathrm{~g}^{-1}$ & 0.79 & 0.84 & 0.80 & 0.79 & 0.030 & 0.875 & 0.882 & 0.492 \\
\hline ash, $\mathrm{g} \cdot 100 \mathrm{~g}^{-1}$ & 1.17 & 1.12 & 1.14 & 1.16 & 0.013 & 0.580 & 0.862 & 0.211 \\
\hline total cholesterol, $\mathrm{mg} \cdot \mathrm{g}^{-1}$ & 20.86 & 20.92 & 19.73 & 22.83 & 0.822 & 0.656 & 0.543 & 0.379 \\
\hline Minolta lightness, $L^{*}$ & 49.01 & 51.80 & 51.65 & 51.63 & 0.461 & 0.087 & 0.055 & 0.114 \\
\hline Minolta redness, $a^{*}$ & 6.29 & 5.24 & 6.17 & 5.60 & 0.217 & 0.337 & 0.977 & 0.320 \\
\hline Minolta yellowness, $b^{*}$ & $10.86^{b}$ & $11.20^{\mathrm{ab}}$ & $12.39^{a}$ & $12.29^{a}$ & 0.235 & 0.034 & 0.007 & 0.611 \\
\hline $\mathrm{pH}_{24 \mathrm{~h}}$ & 5.70 & 5.59 & 5.65 & 5.63 & 0.019 & 0.205 & 0.356 & 0.202 \\
\hline Warner-Bratzler shear force (N) & 7.64 & 7.78 & 8.05 & 8.02 & 0.485 & 0.990 & 0.759 & 0.936 \\
\hline Cooking loss, $\mathrm{g} \cdot 100 \mathrm{~g}^{-1}$ & 26.26 & 26.01 & 27.38 & 26.53 & 0.403 & 0.676 & 0.565 & 0.722 \\
\hline
\end{tabular}

${ }^{1}$ data represent mean values of 7 turkeys per treatment; SEM - standard error of the mean (SD divided by the square root of replication number, $\mathrm{n}=28) ;{ }^{2}$ see Table $1 ;{ }^{\mathrm{a}, \mathrm{b}}$ means with different superscripts within a row are significantly different at $P<0.05$

not affect the sensory attributes of turkey breast meat, including appearance, aroma, taste, or texture (Table 7).

Lupine-based diets affected the fatty acid profile of turkey meat, leading to a significant decrease $(P<0.001)$ in the concentrations of saturated fatty acids (SFAs; Table 8), including lauric acid (C12:0), myristic acid (C14:0) and palmitic acid (C16:0). In comparison with the control group, a linear and statistically significant $(P<0.001)$ increase in the concentrations of PUFAs, including n-6 PUFAs (linoleic acid C18:2) and n-3 PUFAs (linolenic acid C18:3), was noted in meat from turkeys fed lupine-based diets. The above increase did not change the $\mathrm{n}-6 / \mathrm{n}-3$ PUFA ratio $(P=0.838)$, but improved the values of the atherogenic index and thrombogenic index in all groups fed YLMsupplemented diets $(P<0.001)$.

\section{Discussion}

The crude protein content of yellow lupine seeds $\mathrm{cv}$. Baryt reached $414.5 \mathrm{~g} \cdot \mathrm{kg}^{-1}$ of DM, and was slightly higher than in other modern Polish varieties of yellow lupine (Sobotka et al., 2013).
Table 7. Descriptive panel analysis of breast meat sensory attributes in turkeys at 16 weeks of age ${ }^{1}$

\begin{tabular}{llllll}
\hline $\begin{array}{l}\text { Sensory } \\
\text { attributes }\end{array}$ & \multicolumn{2}{l}{ Treatment $^{2}$} & & & \\
\cline { 2 - 5 } $\mathrm{LM}_{0}$ & $\mathrm{LM}_{8}$ & $\mathrm{LM}_{16}$ & $\mathrm{LM}_{24}$ & \\
\hline $\begin{array}{l}\text { Appearance } \\
\text { Aroma }\end{array}$ & 3.17 & 3.12 & 3.14 & 3.13 & 0.969 \\
$\quad$ & & & & & \\
$\quad$ meaty & 6.27 & 6.29 & 6.31 & 6.26 & 0.913 \\
$\quad$ brothy & 4.92 & 4.84 & 4.94 & 4.83 & 0.929 \\
$\quad$ giblet & 3.58 & 3.58 & 3.64 & 3.58 & 0.966 \\
fatty & 1.93 & 1.97 & 1.93 & 2.05 & 0.771 \\
$\quad$ sweet & 0.92 & 0.93 & 0.87 & 0.91 & 0.890 \\
$\quad$ sour & 0.87 & 0.92 & 0.91 & 0.86 & 0.771 \\
Taste & & & & & \\
$\quad$ meaty & 6.57 & 6.61 & 6.49 & 6.47 & 0.504 \\
$\quad$ brothy & 4.26 & 4.26 & 4.15 & 4.38 & 0.497 \\
$\quad$ giblet & 3.42 & 3.48 & 3.38 & 3.57 & 0.704 \\
$\quad$ fatty & 1.59 & 1.54 & 1.48 & 1.62 & 0.533 \\
$\quad$ sweet & 1.00 & 1.08 & 1.08 & 0.97 & 0.252 \\
$\quad$ sour & 1.29 & 1.32 & 1.31 & 1.18 & 0.528 \\
$\quad$ aftertaste & 5.01 & 4.95 & 4.92 & 4.77 & 0.316 \\
Texture & & & & & \\
$\quad$ hardness & 4.00 & 4.18 & 4.06 & 3.99 & 0.561 \\
juiciness & 2.18 & 2.08 & 2.14 & 2.26 & 0.609 \\
stringiness & 3.91 & 3.91 & 3.83 & 3.80 & 0.614 \\
chewiness & 5.13 & 5.28 & 5.07 & 5.09 & 0.686 \\
\hline
\end{tabular}

${ }^{1}$ scale intensity of the attribute from 0 (lowest intensity) to 10 (highest intensity); ${ }^{2}$ see Table 1 
Table 8. The effect of different levels of yellow lupine seed meal on the fatty acid profile (\% of total fatty acids) of breast meat in turkeys at 112 day of age ${ }^{1}$

\begin{tabular}{|c|c|c|c|c|c|c|c|c|}
\hline \multirow{2}{*}{ Fatty acid } & \multicolumn{4}{|c|}{ Treatment $^{2}$} & \multirow{2}{*}{$\begin{array}{l}\text { Pooled } \\
\text { SEM }\end{array}$} & \multicolumn{3}{|l|}{$P$} \\
\hline & $\mathrm{LM}_{0}$ & $\mathrm{LM}_{8}$ & $\mathrm{LM}_{16}$ & $\mathrm{LM}_{24}$ & & group & linear & quadratic \\
\hline C14:0 & $0.78^{a}$ & $0.62^{b}$ & $0.62^{b}$ & $0.55^{c}$ & 0.019 & $<0.001$ & $<0.001$ & 0.065 \\
\hline C14:1 & $0.17^{\mathrm{a}}$ & $0.15^{\mathrm{ab}}$ & $0.13^{c b}$ & $0.10^{c}$ & 0.007 & 0.001 & $<0.001$ & 0.430 \\
\hline C16:0 & $23.19^{a}$ & $21.88^{b}$ & $21.34^{b}$ & $20.17^{c}$ & 0.231 & $<0.001$ & $<0.001$ & 0.742 \\
\hline C16:1 & $5.11^{\mathrm{a}}$ & $5.03^{a}$ & $4.39^{a}$ & $3.21^{b}$ & 0.218 & 0.002 & $<0.001$ & 0.122 \\
\hline C18:0 & 8.07 & 7.40 & 7.61 & 8.11 & 0.145 & 0.242 & 0.805 & 0.052 \\
\hline C18:1 cis9 & 26.45 & 26.54 & 26.74 & 24.61 & 0.323 & 0.061 & 0.055 & 0.073 \\
\hline C18:1 cis11 & $2.18^{a}$ & $2.17^{a}$ & $1.94^{\mathrm{b}}$ & $1.82^{b}$ & 0.042 & 0.001 & $<0.001$ & 0.422 \\
\hline C18:2 n-6 & $25.82^{c}$ & $27.89^{b}$ & $29.20^{b}$ & $31.88^{\mathrm{a}}$ & 0.489 & $<0.001$ & $<0.001$ & 0.565 \\
\hline C18:3 n-6 & 0.26 & 0.28 & 0.34 & 0.30 & 0.016 & 0.346 & 0.231 & 0.334 \\
\hline C18:3 n-3 & $2.28^{c}$ & $2.56^{\mathrm{bc}}$ & $2.81^{\mathrm{ab}}$ & $2.91^{\mathrm{a}}$ & 0.066 & 0.001 & $<0.001$ & 0.362 \\
\hline C20:0 & $0.10^{c}$ & $0.12^{c}$ & $0.15^{b}$ & $0.18^{a}$ & 0.007 & $<0.001$ & $<0.001$ & 0.278 \\
\hline C20:1 & $0.20^{\mathrm{b}}$ & $0.21^{b}$ & $0.28^{a}$ & $0.27^{a}$ & 0.009 & $<0.001$ & $<0.001$ & 0.289 \\
\hline $\mathrm{C} 20: 2 \mathrm{n}-6$ & 0.28 & 0.25 & 0.25 & 0.31 & 0.010 & 0.125 & 0.276 & 0.035 \\
\hline $\mathrm{C} 20: 3 \mathrm{n}-6$ & 0.25 & 0.24 & 0.19 & 0.24 & 0.010 & 0.183 & 0.344 & 0.166 \\
\hline C20:4 n-6 & 2.95 & 2.92 & 2.61 & 3.53 & 0.140 & 0.128 & 0.246 & 0.086 \\
\hline $\mathrm{C} 20: 5 \mathrm{n}-3$ & 0.18 & 0.15 & 0.12 & 0.15 & 0.009 & 0.163 & 0.175 & 0.088 \\
\hline $\mathrm{C} 22: 5 \mathrm{n}-3$ & 0.56 & 0.53 & 0.47 & 0.66 & 0.030 & 0.152 & 0.353 & 0.068 \\
\hline $\mathrm{C} 22: 5 \mathrm{n}-6$ & $0.13^{\mathrm{a}}$ & $0.13^{a}$ & $0.02^{b}$ & $0.05^{\mathrm{ab}}$ & 0.018 & 0.044 & 0.022 & 0.560 \\
\hline $\mathrm{C} 22: 6 \mathrm{n}-3$ & 0.36 & 0.35 & 0.28 & 0.42 & 0.023 & 0.136 & 0.586 & 0.071 \\
\hline SFA & $32.75^{a}$ & $30.50^{b}$ & $30.15^{b}$ & $29.45^{b}$ & 0.309 & $<0.001$ & $<0.001$ & 0.079 \\
\hline UFA & $67.25^{b}$ & $69.50^{\mathrm{a}}$ & $69.85^{a}$ & $70.55^{a}$ & 0.310 & $<0.001$ & $<0.001$ & 0.079 \\
\hline MUFA & $34.18^{a}$ & $34.19^{a}$ & $33.56^{\mathrm{a}}$ & $30.10^{b}$ & 0.528 & 0.008 & 0.003 & 0.060 \\
\hline PUFA & $33.07^{\circ}$ & $35.31^{b}$ & $36.29^{b}$ & $40.45^{\mathrm{a}}$ & 0.589 & $<0.001$ & $<0.001$ & 0.124 \\
\hline n-3 PUFA & $3.38^{\circ}$ & $3.59^{b c}$ & $3.68^{b}$ & $4.15^{\mathrm{a}}$ & 0.065 & $<0.001$ & $<0.001$ & 0.099 \\
\hline n-6 PUFA & $29.69^{c}$ & $31.71^{b}$ & $32.61^{b}$ & $36.30^{\mathrm{a}}$ & 0.527 & $<0.001$ & $<0.001$ & 0.134 \\
\hline n-6/n-3 PUFA & 8.79 & 8.84 & 8.87 & 8.75 & 0.046 & 0.838 & 0.852 & 0.402 \\
\hline $\mathrm{Al}^{3}$ & $0.40^{\mathrm{a}}$ & $0.35^{b}$ & $0.34^{b}$ & $0.32^{\mathrm{c}}$ & 0.006 & $<0.001$ & $<0.001$ & 0.110 \\
\hline $\mathrm{Tl}^{4}$ & $0.76^{\mathrm{a}}$ & $0.68^{b}$ & $0.67^{\mathrm{b}}$ & $0.63^{c}$ & 0.011 & $<0.001$ & $<0.001$ & 0.101 \\
\hline
\end{tabular}

${ }^{1}$ data represent mean values of 7 turkeys per treatment. SEM - standard error of the mean (SD divided by the square root of replication number, $\mathrm{n}=28) ;{ }^{2}$ see Table $1 ; \mathrm{Al}$ - atherogenic index; $\mathrm{TI}$ - thrombogenic index; a,b,c means with different superscripts within a row are significantly different at $P<0.05$

Low concentrations of lysine and methionine, compared with SBM, indicate that the diets should be supplemented with crude amino acids. The alkaloid content of yellow lupine seeds reached $310 \mathrm{mg} \cdot \mathrm{kg}^{-1}$ and was comparable with that reported by Jezierny et al. (2011) and Zduńczyk et al. (2014), but much higher than the $200 \mathrm{mg} \cdot \mathrm{kg}^{-1}$ accepted in the EU. The crude fibre and NSP content of YLM determined in our study considerably exceeded the levels of those components in SBM: it was 4-fold and 3-fold higher, respectively. Non-starch polysaccharides are known to be poorly digested in the upper gastrointestinal tract of monogastric animals, which is an important consideration since broilers and turkeys have relatively short small intestines (Zduńczyk et al., 2013). The levels of $\alpha$-galactosides in the analysed yellow lupine seeds were higher than those reported by other authors (Sobotka et al., 2013).

Recent research demonstrated that yellow lupine seeds can be included at up to $18 \%$ in grower/ finisher diets for turkeys from 13 weeks of age with- out adverse effects on their growth performance, carcass composition or meat quality (Zduńczyk et al., 2014). Our findings show that the inclusion of raw yellow lupine seeds at up to $24 \%$ in turkey diets did not depress the growth rate of birds in the entire experimental period, whereas in the first phase of feeding after hatching, increased YLM levels in the diet led to a linear decrease in FI and BWG. A reverse trend was noted in the second stage of production: BWG increased and FCR improved significantly. In group $\mathrm{LM}_{24}$, lower FI could result from the presence of alkaloids and phenolics in lupine seeds. Even if present in low amounts, those compounds may reduce feed consumption due to their bitter taste. The above may suggest that lupine seeds should be limited in the first period of growth. It may also indicate that turkeys needed a few weeks to adapt themselves to the diets with lupine seeds and that the initial decline in their growth rate was compensated for in the second phase of the trial. A similar adverse effect on FI and BWG was observed by Smulikowska 
et al. (2014) in broilers fed a diet containing $10 \%$ of yellow lupine seeds, and by Zduńczyk et al. (2014) in growing/finishing turkeys fed a diet with $18 \%$ of YLM. It should be underlined that in our experiment, feed efficiency did not deteriorate despite the relatively high amount of YLM $\left(240 \mathrm{~g} \cdot \mathrm{kg}^{-1}\right)$ providing a high dietary load of NSPs and RFOs in comparison with the control treatment. In a study by Nalle et al. (2011), diets containing $20 \%$ of three narrow-leaved lupine cultivars fed to broiler chickens had no effect on BWG, FI or feed utilization compared with a maize-soyabean diet. Feed intake, BWG and FCR were also similar when part of SBM was replaced with $20 \%$ of white lupine seeds in broiler diets (Nalle et al., 2012). However, in another experiment, chicken diets containing $20 \%$ of white lupine seeds contributed to a decrease in BWG and feed efficiency (Viveros et al., 2007).

Our findings did not reveal any negative effects of lupine-based diets on excreta moisture. In this regard, recent research has shown that yellow lupine added at $18 \%$ to turkey diets (Zduńczyk et al., 2014) and at $20 \%$ to broiler diets (Smulikowska et al., 2014) does not cause digesta viscosity problems. In our study, serum biochemical parameters remained within the normal physiological ranges, similarly as in the work of Straková et al. (2008), who noted no adverse effects of diets containing yellow lupine seeds in broiler chickens.

Lupine-based diets did not cause significant changes in carcass characteristics, except for abdominal fat pad and gizzard weights. It appears that the significant increase in relative gizzard weight was an adaptation mechanism to the elevated levels of dietary fibre in the $\mathrm{LM}_{24}$ dietary treatment, as previously reported by Svihus (2011). A rapid and conspicuous enlargement in gizzard size was also observed by Zduńczyk et al. (2014) in 16-week-old turkeys fed a high-fibre diet with 18\% lupine seeds for 6 weeks.

Our results indicate that lupine-based diets did not lead to significant changes in the majority of the physicochemical and sensory properties of turkey meat, which corroborates the findings of Zduńczyk et al. (2014) regarding turkeys fed lupine seeds.

The increase in the concentrations of unsaturated fatty acids in meat from turkeys fed lupinebased diets, noted in our study, is consistent with the results reported by Laudadio and Tufarelli (2011) for broilers. Lupine species differ considerably with regard to lipid fraction composition (Chiofalo et al., 2012). White lupine oil is characterized by the highest $n-3 / n-6$ PUFA ratio (Chiofalo et al., 2012), which is why diets containing white lupine seeds increase n-3 PUFAconcentrations and decrease n-6 PUFA levels in chicken meat
(Mieczkowska and Smulikowska, 2005; Laudadio and Tufarelli, 2011). In comparison with white and blue lupines, yellow lupine oil has a higher content of n-6 PUFAs, mostly linoleic acid (C18:2) and eicosadienoic acid (C20:2). In this experiment, the inclusion of lupine seeds in turkey diets caused a linear increase in both $n-6$ and n-3 PUFA concentrations, without affecting the n-6/n-3 PUFA ratio, and significantly decreased the atherogenic and thrombogenic indices in meat lipids $(P<0.001)$. Our findings are in agreement with previous studies conducted by Laudadio and Tufarelli (2011) who examined the effect of lupine-based diets on meat quality in broiler chickens.

\section{Conclusions}

The results of the present study indicate that starter diets containing 24\% yellow lupine seed meal could have an adverse influence on bird performance. Yellow lupine seeds can be added to diets for older turkeys at up to $24 \%$ as an effective substitute for soyabean meal without affecting the key variables of performance and without negative effects on meat quality.

\section{Acknowledgements}

The study was conducted as part of a long-term programme of the Polish Ministry of Agriculture and Rural Development, entitled 'Improvements in locally grown vegetable protein sources, vegetable protein production and trading systems and the use of vegetable protein sources in animal feeds'.

This experiment was supported by the European Union within the European Social Fund.

\section{References}

AOAC, 2005. Association of Official Analytical Chemists, Official Methods of Analysis. $18^{\text {th }}$ Edition. Arlington, VA

CIE,1978. Recommendations on Uniform Color Spaces, Color Difference Equation, Psychometric Color Terms. Suppl. 2 to CIE Publication No. 15 (E-1.3.1.) 1971/(TC-1-3). CIE, Vienna (Austria)

Chiofalo B., Presti L.V., Chiofalo V., Gresta F., 2012. The productive traits, fatty acid profile and nutritional indices of three lupin (Lupinus spp.) species cultivated in a Mediterranean environment for the livestock. Anim. Feed Sci. Tech. 171, 230-239

Farrell D.J., Perez-Maldonado R.A., Mannion P.F., 1999. Optimum inclusion of field peas, faba beans, chick peas and sweet lupins in poultry diets. II. Broiler experiments. Brit. Poultry Sci. 40, 674-680

Folch J., Lees M., Sloane-Stanley G.H., 1957. A simple method for isolation and purification of total lipides from animal tissues. J. Biol. Chem. 226, 497-509 
Hocking P.M., Mayne R.K., Else R.W., French N.A., Gatcliffe J., 2008. Standard European system for use in turkey processing plants. World Poultry Sci. J. 64, 323-328

Hybrid Turkeys, 2013. Commercial Management Guide. Nutritional Guidelines. Accessed Sept. 22, 2013. http://www.hybridturkeys.com

International Dairy Federation, 1992. Provisional Standard (159): Milk and Milk Fat Product-Determination of Cholesterol Content. IDF, Brussels (Belgium)

Jezierny D., Mosenthin R., Sauer N., Roth S., Piepho H.P., Rademacher M., Eklund M., 2011. Chemical composition and standardised ileal digestibilities of crude protein and amino acids in grain legumes for growing pigs. Livest. Sci. 138, 229-243

Kocher A., Choct M., Hughes R.J., Broz J., 2000. Effect of food enzymes on utilisation of lupin carbohydrates by broilers. Brit. Poultry Sci. 41, 75-82

Kozlowski K., Helmbrecht A., Lemme A., Jankowski J., Jeroch H., 2011. Standardized ileal digestibility of amino acids from highprotein feedstuffs for growing turkeys - a preliminary study. Arch. Geflügelk. 75, 185-190

Laudadio V., Tufarelli V., 2011. Dehulled-micronised lupin (Lupinus albus $\mathrm{L}$. cv. Multitalia) as the main protein source for broilers: influence on growth performance, carcass traits and meat fatty acid composition. J. Sci. Food Agric. 91, 2081-2087

Mieczkowska A., Smulikowska S., 2005. The influence of white lupin seeds in diets supplemented with fats of animal or plant origin on the fatty acid composition of broiler tissues. J. Anim. Feed Sci. 14, 93-107

Muzquiz M., Robredo L.M., Burbano C., Cuadrado C., Ayet G., Mendez P., 1996. Variation in the alkaloid content of different subspecies of Chamaecytisus proliferus from the Canary Islands. J. Chromatogr. A 719, 237-243

Nalle C.L., Ravindran V., Ravindran G., 2011. Nutritional value of narrow-leafed lupin (Lupinus angustifolius) for broilers. Brit. Poultry Sci. 52, 775-781

Nalle C.L., Ravindran V., Ravindran G., 2012. Nutritional value of white lupins (Lupinus albus) for broilers: apparent metabolisable energy, apparent ileal amino acid digestibility and production performance. Animal 6, 579-585

OJEU (Official Journal of the European Union), 2010. Directive 2010/63/EU of the European Parliament and of the Council on the Protection of Animals Used for Scientific Purposes. OJEU 20.10.2010, Series L 276, 33-79

Orda J., Jamroz D., Wiliczkiewicz A., Wertelecki T., Skorupinska J., Broz J., 2006. Effects of increased dietary inclusion of yellow lupins and enzyme supplementation on performance, ileal digestibility of nutrients and microbial status of large intestine in broiler chickens. Arch. Geflügelk. 70, 14-21

Peisker K., 1964. A rapid semi-micro method for preparation of methyl esters from triglycerides using chloroform, methanol, sulphuric acid. J. Amer. Oil Chem. Soc. 11, 87-90
Slominski B.A., Campbell L.D., 1990. Non-starch polysaccharides of canola meal: Quantification, digestibility in poultry and potential benefit of dietary enzyme supplementation. J. Sci. Food Agric. 53, 175-184

Slominski B.A., Guenter W., Campbell L.D., 1993. New approach to water-soluble carbohydrate determination as a tool for evaluation of plant cell wall degradation enzymes. J. Agr. Food Chem. 41, 2304-2308

Smulikowska S., Konieczka P., Czerwinski J., Mieczkowska A., Jankowiak J., 2014. Feeding broiler chickens with practical diets containing lupin seeds (L. angustifolius or L. luteus): effect of incorporation level and mannanase supplementation on growth performance, digesta viscosity, microbial fermentation and gut morphology. J. Anim. Feed Sci. 23, 64-72

Smulikowska S., Rutkowski A. (Editors), 2005. Recommended Allowances and Nutritive Value of Feedstuffs. Poultry Feeding Standards (in Polish). $4^{\text {th }}$ Edition, The Kielanowski Institute of Animal Physiology and Nutrition PAS, Jabłonna (Poland) and Branch of WPSA, pp. 117-119

Sobotka W., Stanek M., Bogusz J., Matusevicius P., 2013. The effect of oligosaccharides and alkaloids contained in yellow and blue lupine seeds on feed intake, body weight and fermentation processes in the cecum of rats. Vet. Med. Zoot. 63, 63-70

StatSoft Inc., 2011. STATISTICA (data analysis software system). Version 10. www.statsoft.com

Straková E., Suchý P., Steinhauser L., Krejčí T., Pospišil R., 2008. Influence of thermally treated and untreated lupin meal on the indicators of performance and health condition of broilers. Acta Vet. Brno 77, 431-437

Svihus B., 2011. The gizzard: function, influence of diet structure and effects on nutrient availability. World Poultry Sci. J. 67, 207-224

Ulbricht T.L., Southgate D.A.T., 1991. Coronary heart disease: Seven dietary factors. Lancet 338, 985-992

Viveros A., Centeno C., Arija I., Brenes A., 2007. Cholesterol-lowering effects of dietary lupin (Lupinus albus var Multolupa) in chicken diets. Brit. Poultry Sci. 86, 2631-2638

Zduńczyk Z., Jankowski J., Juśkiewicz J., Mikulski D., Slominski B.A., 2013. Effect of different dietary levels of low-glucosinolate rapeseed (canola) meal and non-starch polysaccharide-degrading enzymes on growth performance and gut physiology of growing turkeys. Can. J. Anim. Sci. 93, 353-362

Zduńczyk Z., Jankowski J., Mikulski D., Mikulska M., Lamparski G., Slominski B.A., Juśkiewicz J., 2014. Growth performance, gastrointestinal function and meat quality in growing-finishing turkeys fed diets with different levels of yellow lupine (L. luteus) seeds. Arch. Anim. Nutr. 68, 211-226 